\title{
Role of Permeability glycoprotein (P-gp) and Multidrug resistance protein 1 (MRP-1) in drug-resistance in mesial temporal lobe epilepsy
}

\author{
Mandeep Kaur ${ }^{1}$, Tulika Gupta ${ }^{1}$, Mili Gupta ${ }^{2}$, Navneet Singla ${ }^{1}$, Parampreet Singh ${ }^{1}$, \\ Yogendra Bansal ${ }^{1}$, B.D. Radotra ${ }^{1}$, and S.K. Gupta ${ }^{1}$ \\ ${ }^{1}$ Post Graduate Institute of Medical Education and Research \\ ${ }^{2}$ Panjab University
}

January 23, 2021

\begin{abstract}
About $30 \%$ of patients with epilepsy do not respond to anti-epileptic drugs leading to refractory seizures. The pathogenesis of drug-resistance in Mesial Temporal Lobe Epilepsy (MTLE) is not completely understood. Increased activity of drug-efflux transporters might be involved, resulting in subclinical concentrations of the drug at the target site. The major drug-efflux transporters are permeability glycoprotein (P-gp) and multidrug-resistance protein-1 (MRP-1). We have studied these two transporters in the sclerotic hippocampal tissues resected from the epilepsy surgery and compared their expression profile with the tissues resected from non-epileptic autopsy cases. Statistically significant over expression of both P-gp (p-value $<0.0001)$ and MRP-1 (p-value 0.01) at gene and protein levels was found in the MTLE cases. The fold change of P-gp was more pronounced than MRP-1. Immunohistochemistry of patient group showed increased immunoreactivity of P-gp at blood brain barrier and increased reactivity of MRP-1 in parenchyma. The results were confirmed by confocal immunofluorescence microscopy. This suggested that P-gp in association with MRP-1 might be responsible for the multi-drug resistance in epilepsy.
\end{abstract}

\section{Hosted file}

Revised Manuscript.pdf available at https://authorea.com/users/391289/articles/505448-roleof-permeability-glycoprotein-p-gp-and-multidrug-resistance-protein-1-mrp-1-in-drugresistance-in-mesial-temporal-lobe-epilepsy 


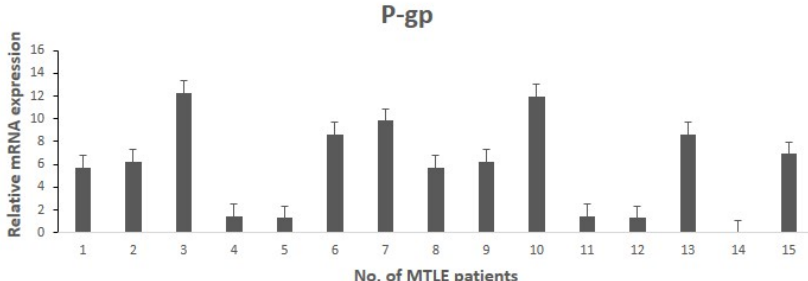

(a)

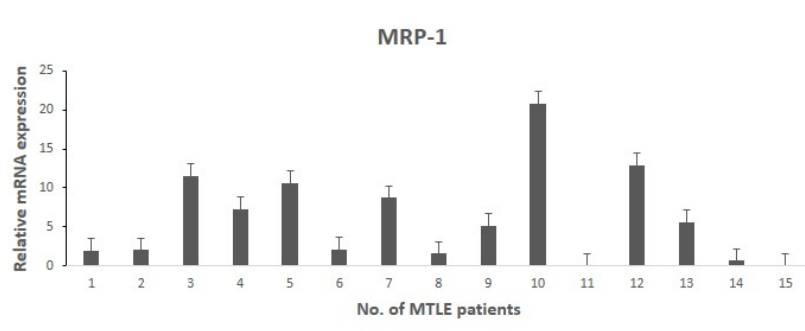

(c)

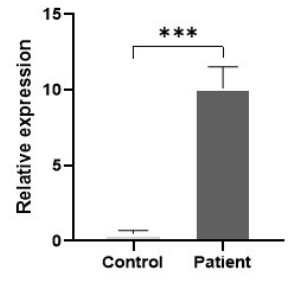

(b)

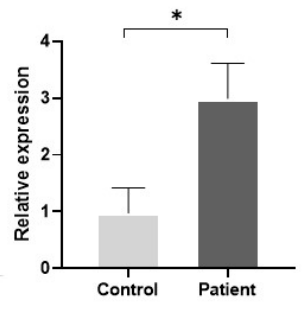

(d)

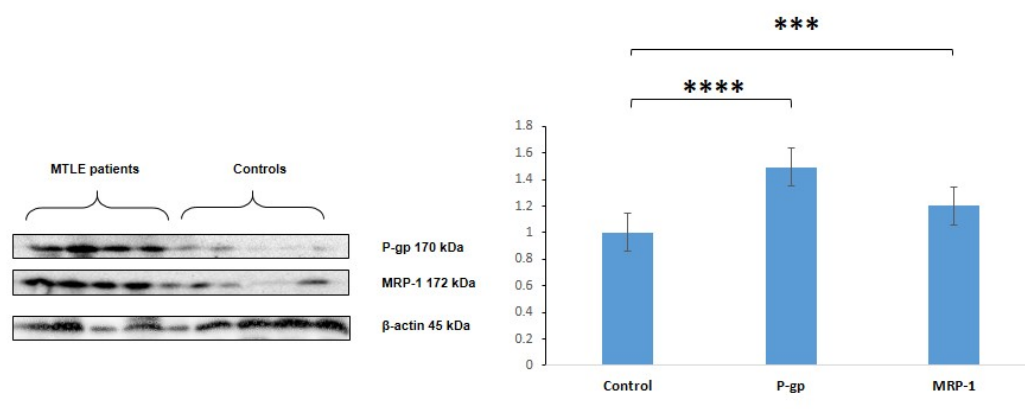

(a)

(b) 

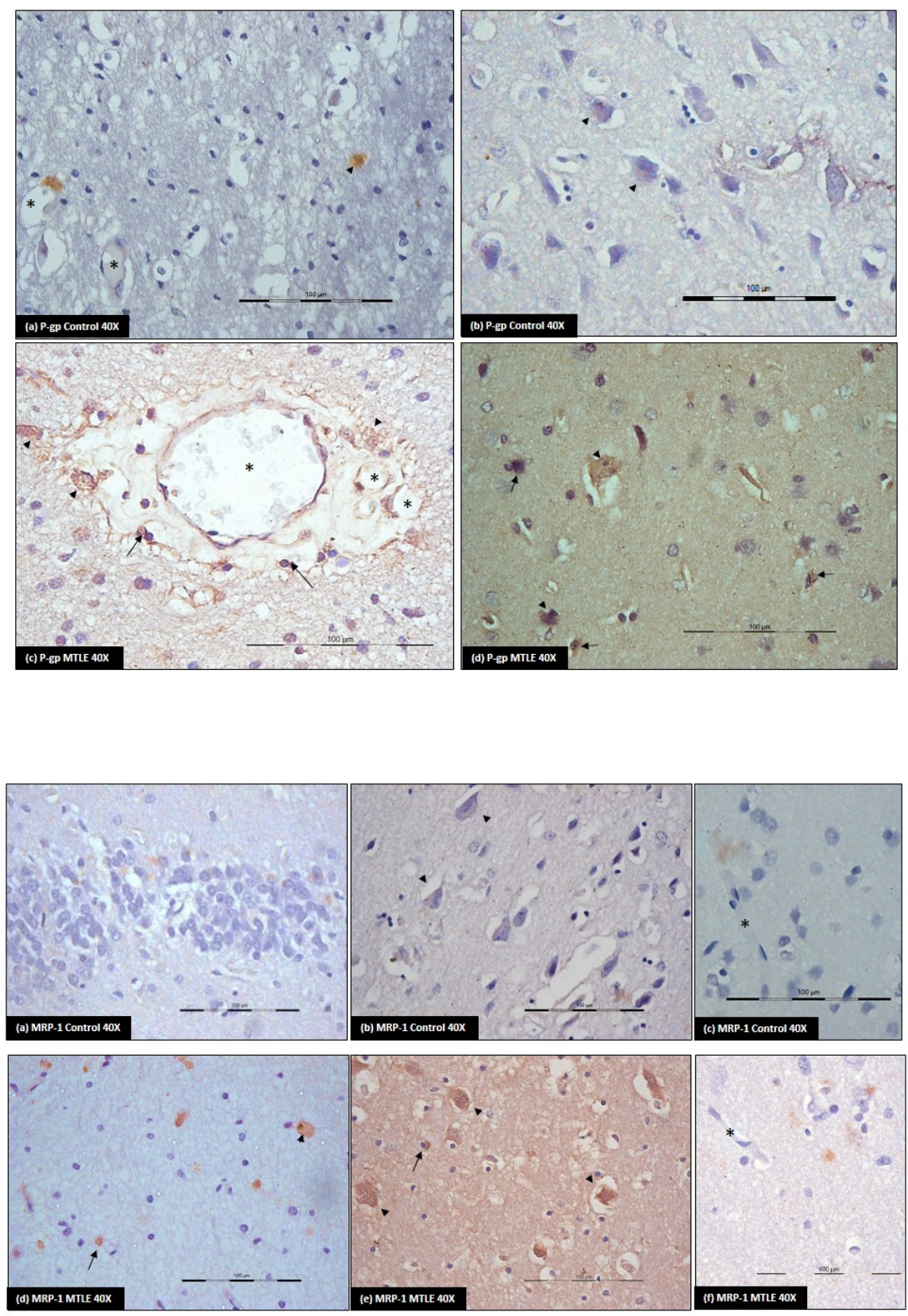


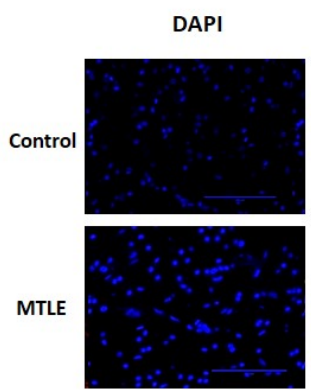

DAPI

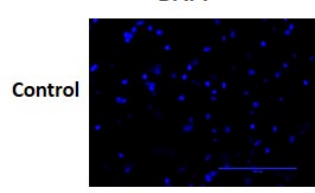

MTLE

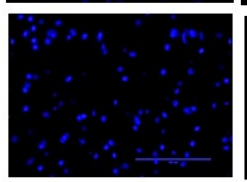

P-gp
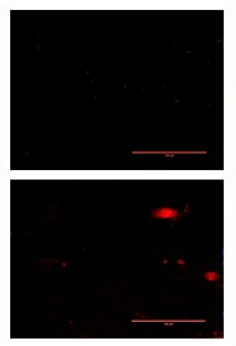

MRP-1
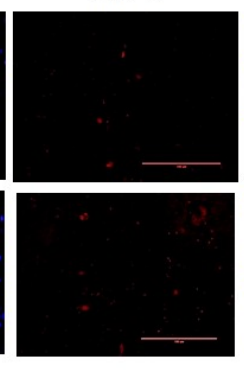

Merged
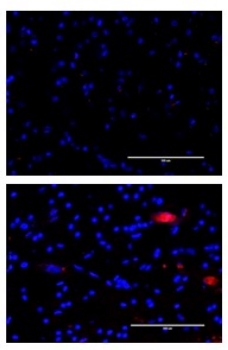

Merged

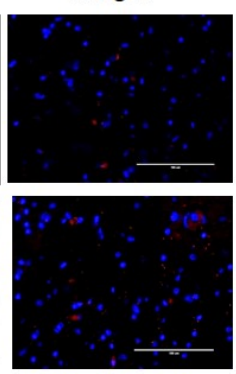

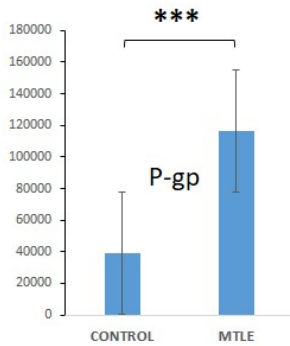

CONTROL MTE

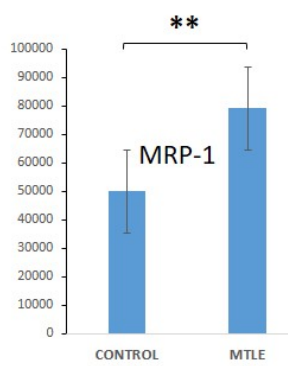

\section{Hosted file}

Table 1.pdf available at https://authorea.com/users/391289/articles/505448-role-ofpermeability-glycoprotein-p-gp-and-multidrug-resistance-protein-1-mrp-1-in-drugresistance-in-mesial-temporal-lobe-epilepsy

\section{Hosted file}

Table 2.pdf available at https://authorea.com/users/391289/articles/505448-role-ofpermeability-glycoprotein-p-gp-and-multidrug-resistance-protein-1-mrp-1-in-drugresistance-in-mesial-temporal-lobe-epilepsy

\section{Hosted file}

Table 3.pdf available at https://authorea.com/users/391289/articles/505448-role-ofpermeability-glycoprotein-p-gp-and-multidrug-resistance-protein-1-mrp-1-in-drugresistance-in-mesial-temporal-lobe-epilepsy 